\title{
Analyst
}

Check for updates

Cite this: Analyst, 2019, 144, 2556

\section{A near-infrared fluorescent probe for evaluating endogenous hydrogen peroxide during ischemia/reperfusion injury $\dagger$}

\author{
Runfeng $\mathrm{Xu}{ }^{\mathrm{a}, \mathrm{b}}$ Yue Wang, ${ }^{\mathrm{b}, \mathrm{c}}$ Huiyan You, ${ }^{{ }^{\mathrm{a}}}$ Liangwei Zhang, ${ }^{{ }^{\mathrm{b}}}$ Yunqing Wang ${ }^{\mathrm{b}}$ and \\ Lingxin Chen (D)*b,d
}

Received 3rd February 2019, Accepted 6th March 2019

DOI: 10.1039/c9an00243j rsc.li/analyst

\begin{abstract}
Hydrogen peroxide $\left(\mathrm{H}_{2} \mathrm{O}_{2}\right)$, as a major component of reactive oxygen species (ROS), plays an important role in normal physiological processes. $\mathrm{A}_{2} \mathrm{O}_{2}$ burst also occurs in the ischemia/reperfusion (I/R) process and causes a series of physiological and pathological injuries. Therefore, it is important to determine concentration fluctuations of $\mathrm{H}_{2} \mathrm{O}_{2}$. Here we develop a ratiometric fluorescent probe, $\mathrm{Cy}$-ArB, which shows high selectivity and sensitivity toward $\mathrm{H}_{2} \mathrm{O}_{2}$. The fluorescence response of the probe is triggered by the reaction of borate esters with $\mathrm{H}_{2} \mathrm{O}_{2}$, and this process releases a near-infrared heptamethine cyanine fluorophore which has the ability of mitochondrial tracing. Hence, the probe can be used for real-time monitoring of $\mathrm{H}_{2} \mathrm{O}_{2}$ fluctuations in the mitochondrial respiration chain. Finally, we explore the fluctuations of $\mathrm{H}_{2} \mathrm{O}_{2}$ in cells and in vivo during the I/R process using the probe Cy-ArB. The results of our experiments prove that our probe is a potential candidate for clinical surgery pre-evaluation.
\end{abstract}

\section{Introduction}

Hydrogen peroxide $\left(\mathrm{H}_{2} \mathrm{O}_{2}\right)$ is a major signaling molecule for oxidative stress in living systems, because it connects with certain enzymes that play an important role in intracellular signal transmission. ${ }^{1} \mathrm{H}_{2} \mathrm{O}_{2}$ is a member of the reactive oxygen species (ROS) family; other ROS include superoxide anions $\left(\mathrm{O}_{2}{ }^{--}\right)$, hydroxyl radicals $\left({ }^{\circ} \mathrm{OH}\right)$, singlet oxygen $\left({ }^{1} \mathrm{O}_{2}\right)$, hypochlorite $\left(\mathrm{OCl}^{-}\right)$and peroxyl radicals $\left(\mathrm{ROO}^{\circ-}\right) .^{1-3}$ The mitochondrial metabolic process is the main source of $\mathrm{H}_{2} \mathrm{O}_{2}$ generation in aerobic cells and tissues. ${ }^{12}$ Previous work has demonstrated that the concentration of $\mathrm{H}_{2} \mathrm{O}_{2}$ is higher than that of other ROS family members in the intracellular environment. ${ }^{4} \mathrm{H}_{2} \mathrm{O}_{2}$ is involved in many cellular processes, such as apoptosis, signal transduction, neurodegenerative injury and inflammation.

Hepatic ischemia/reperfusion (I/R) injury is a common complication in clinical treatment, normally occurring in liver

\footnotetext{
${ }^{a}$ School of Environment and Chemical Engineering, Dalian University, Dalian 116622, China.E-mail: dlyhy@dicp.ac.cn

${ }^{b}$ CAS Key Laboratory of Coastal Environmental Processes and Ecological Remediation, Yantai Institute of Coastal Zone Research, Chinese Academy of Sciences, Yantai 264003, China. E-mail: liangweizhang@yic.ac.cn, lxchen@yic.ac.cn ${ }^{c}$ University of Chinese Academy of Sciences, Beijing 100049, China

${ }^{d}$ College of Chemistry and Chemical Engineering, Qufu Normal University, Qufu 273165, China

$\dagger$ Electronic supplementary information (ESI) available. See DOI: 10.1039/ c9an00243j
}

transplantation, major resection and frequent liver ischemia. ${ }^{5}$ It is an unavoidable problem in liver surgery. ${ }^{6,7}$ Therefore a thorough understanding of the hepatic $\mathrm{I} / \mathrm{R}$ process could reduce liver failure. ${ }^{8}$ Evaluation of the degree of liver injury is crucial to recovery from liver resection surgery. From the literature, we find that tissue damage and cell injury happen in the hepatic I/R process. This is perhaps associated with biochemical and biological effects of radicals and oxidants. ${ }^{9,10} \mathrm{H}_{2} \mathrm{O}_{2}$, as an important member of the ROS family, may be involved in this process. In order to study the roles of $\mathrm{H}_{2} \mathrm{O}_{2}$ in these physiological processes, we attempt to investigate links between the I/R process and concentration fluctuations of $\mathrm{H}_{2} \mathrm{O}_{2} \cdot{ }^{11,12}$

Fluorescence imaging technology is applied to detect the signal molecules in real-time via change in optical properties. ${ }^{13-20}$ It is worth mentioning that the detection of $\mathrm{H}_{2} \mathrm{O}_{2}$ by nanomaterials has received extensive attention, ${ }^{25-27}$ such as biomineralized gold containing proteins that detect $\mathrm{H}_{2} \mathrm{O}_{2}$. Compared with other detection methods, fluorescence imaging technology is an excellent method for non-invasive monitoring of the concentration fluctuations of $\mathrm{H}_{2} \mathrm{O}_{2} \cdot{ }^{21-24}$ Aiming to identify the changes during the liver I/R process, Han et al. showed that there was an increase of $\mathrm{O}_{2}{ }^{--}$in mitochondria during the hepatic I/R process. They also evaluated the relationship between the level of $\mathrm{O}_{2}{ }^{--}$and the degree of organ damage during the $\mathrm{I} / \mathrm{R}$, ischemic preconditioning (IPC) and ischemic postconditioning (IPTC) processes. ${ }^{12}$ Inspired by this work, we attempt to evaluate the relationship between 
$\mathrm{H}_{2} \mathrm{O}_{2}$, the downstream product of $\mathrm{O}_{2}{ }^{--}$, and the degree of organ damage during the liver I/R process.

In this study, we synthesized a fluorescent probe Cy-ArB to detect the concentrations of $\mathrm{H}_{2} \mathrm{O}_{2}$ in living cells and in vivo during the I/R process. The probe was composed of two components: the near-infrared (NIR) fluorophore heptamethine cyanine and the response unit borate ester groups. We took advantage of heptamethine cyanine as fluorophore because it could be used for mitochondrial tracing. ${ }^{28}$ The results demonstrated that our probe could sensitively detect the endogenous $\mathrm{H}_{2} \mathrm{O}_{2}$ concentration changes in mitochondria. Moreover, the probe could accurately reflect the endogenous $\mathrm{H}_{2} \mathrm{O}_{2}$ concentration fluctuations in cells and in vivo during $\mathrm{I} / \mathrm{R}$ processes. We further estimated the relationship between $\mathrm{H}_{2} \mathrm{O}_{2}$ concentration and degree of organ damage.

\section{Experimental section}

\section{Establishment of cell I/R models}

For the establishment of cell I/R models, HepG2 cells were treated by different methods. Group a: glucose deprivation/ reperfusion. Cells were incubated in Dulbecco's modified Eagle's medium (DMEM) but glucose free for $30 \mathrm{~min}$ at $37^{\circ} \mathrm{C}$ under stable atmosphere containing $5 \% \mathrm{CO}_{2}$. Subsequently, it treated by normal full component DMEM culture-medium at $37{ }^{\circ} \mathrm{C}$ under a stable atmosphere containing $5 \% \mathrm{CO}_{2}$. Group b: serum deprivation/reperfusion. Cells were incubated in DMEM medium but serum free for $30 \mathrm{~min}$ at $37{ }^{\circ} \mathrm{C}$ under a stable atmosphere containing $5 \% \mathrm{CO}_{2}$. Subsequently, it treated by normal full component DMEM culture-medium. Group c: oxygen deprivation/reperfusion. Cells were incubated in DMEM medium for $30 \mathrm{~min}$ at $37{ }^{\circ} \mathrm{C}$ under a stable atmosphere containing $95 \% \mathrm{~N}_{2}$ and $5 \% \mathrm{CO}_{2}$. Subsequently, it treated by normal full component DMEM culture-medium at $37^{\circ} \mathrm{C}$ under a stable atmosphere containing $5 \% \mathrm{CO}_{2}$. Group d: glucoseserum-oxygen deprivation/reperfusion. Cells were incubated in DMEM medium but glucose and serum free for $30 \mathrm{~min}$ at $37{ }^{\circ} \mathrm{C}$ under a stable atmosphere containing 95\% $\mathrm{N}_{2}$ and $5 \%$ $\mathrm{CO}_{2}$. Subsequently, it treated by normal full component DMEM culture-medium at $37{ }^{\circ} \mathrm{C}$ under a stable atmosphere containing $5 \% \mathrm{CO}_{2}$.

\section{Establishment of mice hepatic I/R models}

To establish the mice hepatic I/R models, BALB/c mice were treated by different methods. Group a: sham operation group mice were opened at the abdomen, maintaining normal hepatic blood flow. Group b: I/R group mice had the portal vein and hepatic artery clamped for $2.5 \mathrm{~h}$ with a traumatic vascular clamp. After termination of hypoxic exposure, we removed the clamp to ensure normal hepatic blood flow.

\section{Synthesis of probe Cy-ArB}

Compound $\mathrm{Cy}-\mathrm{NH}$ was synthesized according to the reported procedure. $^{29}$ Cy-NH (0.05 g, $\left.0.1 \mathrm{mmol}\right)$ and triphosgene $\left(12.0 \mathrm{mg}, 0.04 \mathrm{mmol}\right.$ ) were dissolved in anhydrous $\mathrm{CH}_{2} \mathrm{Cl}_{2}$ under Ar atmosphere. Then the reaction flask was cooled to $0{ }^{\circ} \mathrm{C}$ for $10 \mathrm{~min}$. Triethylamine $(12.1 \mathrm{mg}, 0.12 \mathrm{mmol})$ was dissolved in anhydrous $\mathrm{CH}_{2} \mathrm{Cl}_{2}$, and then added dropwise into the cooled solution. An obviously color change appeared in the solution. The reaction was quenched with cooled saturated aqueous $\mathrm{NaHCO}_{3}$ when the color was completely converted to green, and then the product was dissolved in anhydrous $\mathrm{CH}_{2} \mathrm{Cl}_{2}$ after removing solvents under vacuum. Subsequently, triethylamine (30.3 $\mathrm{mg}, 0.3 \mathrm{mmol}$ ) was dissolved in $2.0 \mathrm{~mL}$ $\mathrm{CH}_{2} \mathrm{Cl}_{2}$ and added to the mixture for $1 \mathrm{~h}$. Then $(4-(4,4,5,5-$ tetramethyl-1,3,2-dioxaborolan-2-yl)phenyl) methanol (0.07 g, $0.3 \mathrm{mmol}$ ) and 4-dimethylaminopyridine (DMAP) (20 mg) were added to the solution. The reaction was monitored by TLC. The mixture was washed three times with saturated brine solution and extracted with $\mathrm{CH}_{2} \mathrm{Cl}_{2}(20 \mathrm{~mL} \times 3)$. The organic phase was purified by silica column chromatography (200-300 mesh) with a gradient eluent of $\mathrm{CH}_{2} \mathrm{Cl}_{2}$ and $\mathrm{CH}_{3} \mathrm{OH}$ (75:25 to $50: 50, \mathrm{v} / \mathrm{v})$. After removing the organic phase under vacuum, a dark green solid, Cy-ArB, was obtained. ${ }^{1} \mathrm{H}$ NMR $(500 \mathrm{MHz}$, $\left.\mathrm{CDCl}_{3}-d 1\right) \delta(\mathrm{ppm}): 7.63(\mathrm{~d}, 2 \mathrm{H}), 7.57$ (d, 2H), 7.43-7.36 (m, 2H), $7.32(\mathrm{~d}, 2 \mathrm{H}), 7.25-7.14(\mathrm{~m}, 6 \mathrm{H}), 6.24(\mathrm{~d}, 2 \mathrm{H}), 5.13$ (s, $2 \mathrm{H}), 4.13$ (q, 4H), 3.29 (s, 3H), $1.64(\mathrm{~s}, 6 \mathrm{H}), 1.46(\mathrm{~m}, 6 \mathrm{H}), 1.39$ (s, 6H), 1.27 (m, 6H), 1.21 (s, 12H) (Fig. S8†). LC-MS (API-ES): $m / z \mathrm{C}_{49} \mathrm{H}_{61} \mathrm{BN}_{3} \mathrm{O}_{4}{ }^{+}$calcd 766.69 , found $\left[\mathrm{M}^{+}\right] 766.69$ (Fig. $\mathrm{S} 7 \dagger$ ). Other materials, instruments and experimental methods are described in the ESI. $\dagger$

\section{Results and discussion}

\section{Design of Cy-ArB}

It is well known that $\mathrm{H}_{2} \mathrm{O}_{2}$ can react with arylboronic acids and convert them to phenols. ${ }^{30}$ Borate esters react easily with $\mathrm{H}_{2} \mathrm{O}_{2}$ to form phenol groups under weak alkaline conditions. ${ }^{31-43}$ Heptamethine cyanine is a fluorescent dye with NIR emission that locates to the mitochondria. The meso-position of this fluorophore is easily modified by various electron-donors which affects its intermolecular electron distribution and leads to ICT-induced blue or red shifts in the emission spectrum. ${ }^{4-44}$ Based on this principle, our probe Cy-ArB was obtained by conjugating borate ester groups to the skeleton of heptamethine cyanine through ester bridge bonds (Scheme 1a). Ratiometric fluorescent probes, which take advantage of the ratio of the spectra, can eliminate disturbances caused by the excitation and emission efficiency, and accurately reflect the $\mathrm{H}_{2} \mathrm{O}_{2}$ concentration level changes during the $\mathrm{I} / \mathrm{R}$ process. The response mechanism of our fluorescent probe for detection of $\mathrm{H}_{2} \mathrm{O}_{2}$ is shown in Scheme 1b. Compared with previously developed probes, our probe Cy-ArB has many advantages, for example the NIR fluorescence emission could maximize tissue penetration while minimizing absorbance by heme in hemoglobin, myoglobin, water, and lipids; ${ }^{60}$ the ratiometric signals could eliminate disturbance caused by the excitation and emission efficiency and variable factors derived from uneven loading or inhomogeneous distribution of the probes as well as environmental conditions. ${ }^{12}$ 
a

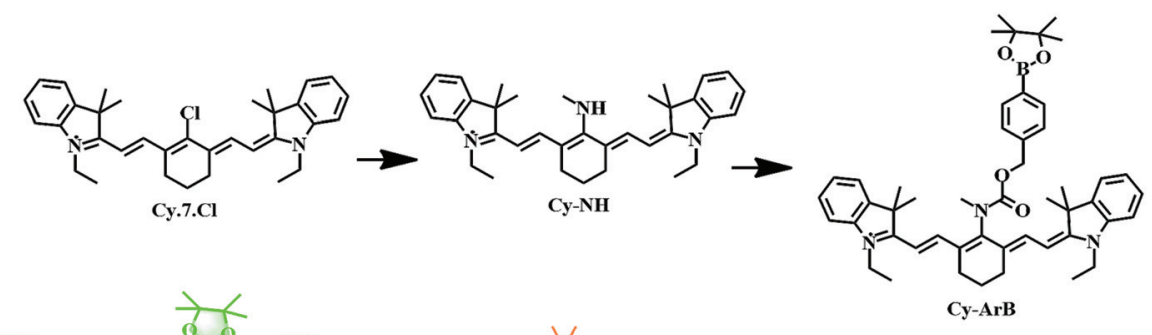

b
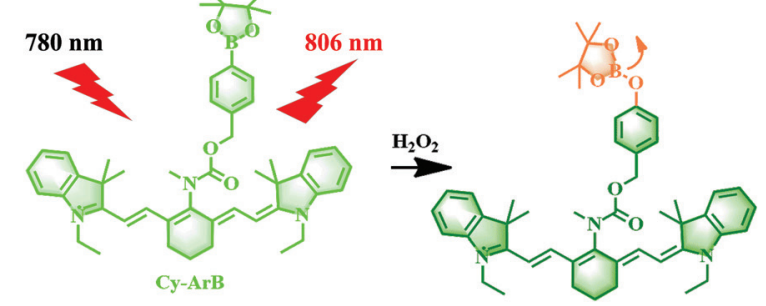

$\rightarrow$
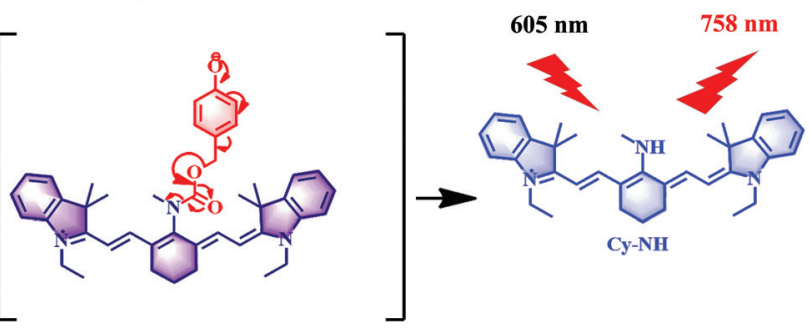

Scheme 1 Synthesis route and the proposed detection mechanism of Cy-ArB toward $\mathrm{H}_{2} \mathrm{O}_{2}$.

\section{Spectral studies of Cy-ArB toward $\mathrm{H}_{2} \mathrm{O}_{2}$}

The spectral properties of the probe Cy-ArB were investigated in HEPES buffer (10 mM, pH 7.4) under simulated conditions. Cy-ArB changed from green to blue after reaction with $\mathrm{H}_{2} \mathrm{O}_{2}$, and the maximum absorption wavelength changed from $780 \mathrm{~nm}$ $\left(\varepsilon=3.4 \times 10^{4} \mathrm{M}^{-1} \mathrm{~cm}^{-1}\right)$ to $605 \mathrm{~nm}\left(\varepsilon=2.8 \times 10^{4} \mathrm{M}^{-1} \mathrm{~cm}^{-1}\right)$
(Fig. 1a). As shown in Fig. 1b and c, the fluorescence signal at $806 \mathrm{~nm}$ decreased. At the same time, the fluorescence signal at $758 \mathrm{~nm}$ increased in the emission spectrum. The probe displayed a large Stokes shift. There was a linear relationship between the logarithm of the ratio $F_{758 \mathrm{~nm}} / F_{806} \mathrm{~nm}$ and the concentration of $\mathrm{H}_{2} \mathrm{O}_{2}$ (Fig. 1d); the standard curve was $\lg \left(F_{758 \mathrm{~nm}} / F_{806} \mathrm{~nm}\right)=0.20 \times\left[\mathrm{H}_{2} \mathrm{O}_{2}\right] \mu \mathrm{M}-0.60(r=0.9814)$. The
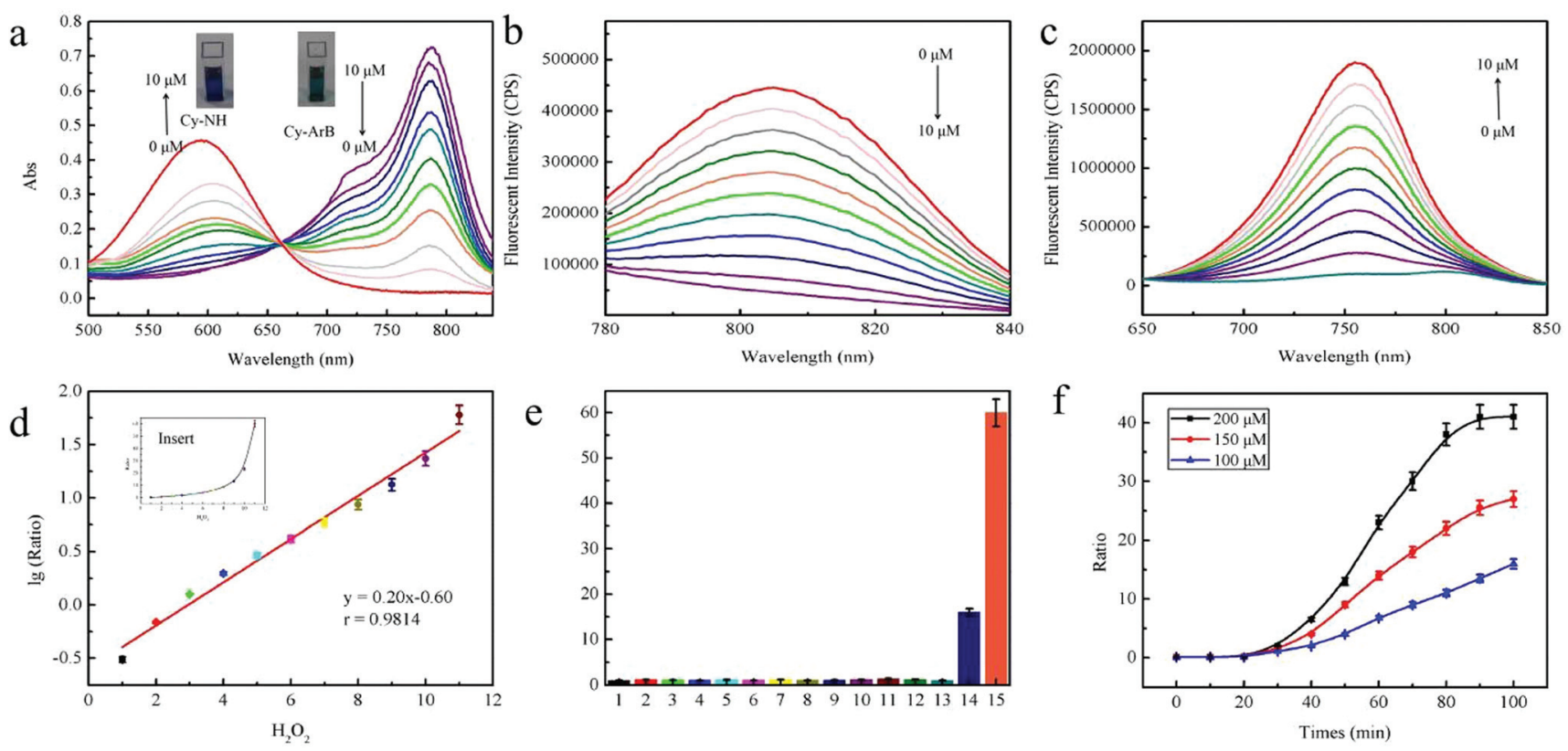

Fig. 1 Spectral responses of Cy-ArB $(10 \mu \mathrm{M})$ towards $\mathrm{H}_{2} \mathrm{O}_{2}(0-200 \mu \mathrm{M})$ within 30 min at $37^{\circ} \mathrm{C}$ (HEPES, pH 7.4, $\left.10 \mathrm{mM}\right)$. (a) Dose-dependent absorbance spectra of $\mathrm{Cy}$-ArB towards $\mathrm{H}_{2} \mathrm{O}_{2}$. (b) Emission spectra of $\mathrm{Cy}$-ArB towards $\mathrm{H}_{2} \mathrm{O}_{2}\left(\lambda_{\text {ex }}=780 \mathrm{~nm}, \lambda_{\text {em }}=790 \mathrm{~nm}-820 \mathrm{~nm}\right.$ ). (c) Emission spectra of Cy-ArB towards $\mathrm{H}_{2} \mathrm{O}_{2}\left(\lambda_{\mathrm{ex}}=605 \mathrm{~nm}, \lambda_{\mathrm{em}}=720 \mathrm{~nm}-770 \mathrm{~nm}\right)$. (d) The linear fitting curve between the $\lg \left(F_{758 \mathrm{~nm}} / F_{806 \mathrm{~nm}}\right)$ and the concentrations of $\mathrm{H}_{2} \mathrm{O}_{2}$. Inset: Intensity ratio $\left(F_{758} \mathrm{~nm} / F_{806} \mathrm{~nm}\right)$ of $\mathrm{Cy}$-ArB change with different concentrations of $\mathrm{H}_{2} \mathrm{O}_{2}$. (e) Fluorescence responses of Cy-ArB towards

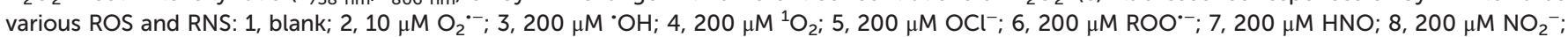

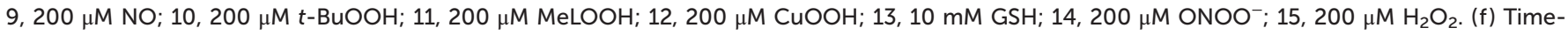
dependent intensity ratio $F_{758} \mathrm{~nm} / F_{806} \mathrm{~nm}$ of $\mathrm{Cy}-\mathrm{ArB}(10 \mu \mathrm{M})$ towards $\mathrm{H}_{2} \mathrm{O}_{2}(100 \mu \mathrm{M}, 150 \mu \mathrm{M}, 200 \mu \mathrm{M})$ during $100 \mathrm{~min} . F_{758 \mathrm{~nm}}: \lambda_{\mathrm{ex}}=605 \mathrm{~nm}$, $\lambda_{\mathrm{em}}=758 \mathrm{~nm} ; F_{806 \mathrm{~nm}}: \lambda_{\mathrm{ex}}=780 \mathrm{~nm}, \lambda_{\mathrm{em}}=806 \mathrm{~nm}$. 
experimental detection limit was determined to be $60 \mu \mathrm{M}$. The theoretical detection limit was calculated to be as low as $20 \mu \mathrm{M}$ $(3 \sigma / \kappa)$, where $\sigma$ is the standard deviation of the blank measurement, and $\kappa$ is the slope of the regression equation. All of these results indicated that Cy-ArB had a good capability for $\mathrm{H}_{2} \mathrm{O}_{2}$ detection under simulated conditions.

Then the selectivity and sensitivity of Cy-ArB were determined using a series of reactive oxygen species (ROS) and reactive nitrogen species (RNS), including hydrogen peroxide $\left(\mathrm{H}_{2} \mathrm{O}_{2}\right)$, superoxide anion $\left(\mathrm{O}_{2}{ }^{\cdot-}\right)$ hydroxyl radical $\left({ }^{\circ} \mathrm{OH}\right)$, singlet oxygen $\left({ }^{1} \mathrm{O}_{2}\right)$, hypochlorite $\left(\mathrm{OCl}^{-}\right)$, peroxyl radicals $\left(\mathrm{ROO}^{-}\right)$, nitroxyl ( $\mathrm{HNO})$, nitrite ion $\left(\mathrm{NO}_{2}{ }^{-}\right)$, nitric oxide (NO), tert-butylhydroperoxide $(t-\mathrm{BuOOH})$, methyl linoleate hydroperoxide $(\mathrm{MeLOOH})$, cumene hydroperoxide $(\mathrm{CuOOH})$ and peroxynitrite $\left(\mathrm{ONOO}^{-}\right)$. All ROS and RNS were prepared as reported previously. ${ }^{45-54}$ The results showed that Cy-ArB could selectively respond to $\mathrm{H}_{2} \mathrm{O}_{2}$ without the interference from other potential intracellular ROS and RNS (Fig. 1e). It is worth mentioning that a large amount of glutathione (GSH; millimolar level) exists in vivo. Thus we investigated whether GSH affected Cy-ArB detection. As shown in Fig. 1e, $10 \mathrm{mM}$ GSH did not interfere with $\mathrm{H}_{2} \mathrm{O}_{2}$ detection. However, peroxynitrite $\left(\mathrm{ONOO}^{-}\right)$ could induce a small signal change, but the fluorescence intensity was much weaker than that of $\mathrm{H}_{2} \mathrm{O}_{2}$. $\mathrm{ONOO}^{-}$has a short half-life (about $10 \mathrm{~ms}$ ) and low steady-state concentration (nanomolar level), ${ }^{58}$ while $\mathrm{H}_{2} \mathrm{O}_{2}$ has a steady-state concentration much higher (micromolar level) than that of $\mathrm{ONOO}^{-59}$ Thus our probe Cy-ArB can be used for $\mathrm{H}_{2} \mathrm{O}_{2}$ detection with good selectivity in living cells and in vivo. Benefiting from this high selectivity towards $\mathrm{H}_{2} \mathrm{O}_{2}$, we inspected the time-dependent reaction kinetics of $\mathrm{Cy}$-ArB with different concentrations of $\mathrm{H}_{2} \mathrm{O}_{2}(100 \mu \mathrm{M}, 150 \mu \mathrm{M}, 200 \mu \mathrm{M})$. According to Fig. 1f, the fluorescence signal of Cy-ArB with $\mathrm{H}_{2} \mathrm{O}_{2}(200 \mu \mathrm{M})$ reached saturation within $70 \mathrm{~min}$ (the raw data are shown in Fig. $\mathrm{S} 1 \dagger$ ). These results indicated that $\mathrm{Cy}$-ArB as a NIR ratiometric fluorescent probe offered high selectivity and sensitivity toward $\mathrm{H}_{2} \mathrm{O}_{2}$ under physical conditions.

\section{Imaging of $\mathrm{Cy}$-ArB response to $\mathrm{H}_{2} \mathrm{O}_{2}$}

Prior to investigation in living cells, MTT (3-(4,5-dimethylthiazol-2-yl)-2,5-diphenyltetrazolium bromide) assays were performed to check the cytotoxicity of $\mathrm{Cy}-\operatorname{ArB}(0,10,20,30,40,50$, $60,70,80 \mu \mathrm{M})$ (Fig. S5 $\dagger$ ). Furthermore, the stability of Cy-ArB at different $\mathrm{pH}$ values and temperatures was explored (Fig. S2 and $\mathrm{S} 3 \dagger$ ). According to the experimental results, was stable at different $\mathrm{pH}$ values (4.0-8.0) and different temperatures $\left(10^{\circ} \mathrm{C}-40^{\circ} \mathrm{C}\right)$. In addition, the photo-stability of Cy-ArB was tested (Fig. S4 $\dagger$ ), and it was found that our probe was stable in the air for 7 days. These results demonstrated that Cy-ArB was stable enough to meet our experimental requirements. To test the biological practicability of the probe, we attempted to image endogenous $\mathrm{H}_{2} \mathrm{O}_{2}$ level in human hepatocellular liver carcinoma (HepG2) cells. Cell imaging experiments were performed by laser scanning confocal microscopy and the cells were treated with $10 \mu \mathrm{M}$ Cy-ArB for $30 \mathrm{~min}$ at $37{ }^{\circ} \mathrm{C}$ in a thermostat. As shown in Fig. 2a, we used two detection channels for imaging: channel 1 (Ch1): $\lambda_{\mathrm{ex}}=635 \mathrm{~nm}, \lambda_{\mathrm{em}}=$ $720 \mathrm{~nm}-770 \mathrm{~nm}$; channel 2 (Ch2): $\lambda_{\mathrm{ex}}=730 \mathrm{~nm}, \lambda_{\mathrm{em}}=790 \mathrm{~nm}-$ $820 \mathrm{~nm}$. As shown in Fig. 2a, after the cells were incubated with probe, strong fluorescence signal in Ch2 and weak fluorescence signal in Ch1 were observed. The mitochondrion is the center for redox reaction in cells. Aiming at detecting endogenous $\mathrm{H}_{2} \mathrm{O}_{2}$ concentration fluctuations in mitochondria, we performed multicolor co-localization assays to confirm that Cy-ArB locates to mitochondria. Rhodamine 123 is a commercial mitochondria-targeting dye with $\lambda_{\mathrm{ex}}=515 \mathrm{~nm}$ and $\lambda_{\mathrm{em}}=$ $550 \mathrm{~nm}-600 \mathrm{~nm}$. Hoechst 33342 is a commercial nucleustargeting dye with $\lambda_{\text {ex }}=405 \mathrm{~nm}$ and $\lambda_{\mathrm{em}}=420 \mathrm{~nm}-480 \mathrm{~nm}$. The images were collected, with the green channel representing Rhodamine 123 fluorescence imaging and the blue channel representing Hoechst 33342 fluorescence (Fig. S6†). As shown in Fig. 2a, the probe hardly showed any overlap with the nucleus dye Hoechst 33342 (merged red and blue channels). While the fluorescence overlay image from Cy-ArB and Rhodamine 123 exhibited an excellent anastomosis in mitochondria (merged red and green channels). Intensity profiles of regions of interest (red arrow) across HepG2 cells (merged red, green and blue channels) varied in close synchrony. The above results demonstrated that our probe could target mitochondria and detect the endogenous $\mathrm{H}_{2} \mathrm{O}_{2}$ in living cells.

To verify the potential ability of the probe, we used the probe to monitor the endogenous $\mathrm{H}_{2} \mathrm{O}_{2}$ concentration fluctuations in HepG2 cells. As far as we know, rotenone can promote $\mathrm{H}_{2} \mathrm{O}_{2}$ generation ${ }^{55}$ because this agent can combine with ubiquinone and block complex I (NADH: ubiquinone oxidoreductase) in the electron-transport chain. Mito-TEMPO is a commercial mitochondria-targeting superoxide scavenger that can eliminate endogenous $\mathrm{H}_{2} \mathrm{O}_{2} \cdot{ }^{56}$ HepG2 cells were incubated with $20 \mu \mathrm{M}$ totenone and $100 \mu \mathrm{M}$ mito-TEMPO for $30 \mathrm{~min}$, respectively. As illustrated in Fig. $2 \mathrm{~b}-\mathrm{d}$, obvious fluorescence signals were observed when the cells were treated with rotenone. Oppositely, the fluorescence decreased significantly when the cells were treated with mito-TEMPO. These results suggest that the probe could be used for monitoring endogenous $\mathrm{H}_{2} \mathrm{O}_{2}$ level changes in living cells. To further confirm the obtained results, we detected endogenous $\mathrm{H}_{2} \mathrm{O}_{2}$ levels by flow cytometry analysis. The results of the flow cytometry analysis are shown in Fig. $2 \mathrm{e}-\mathrm{g}$ and consistent with the results recorded by confocal fluorescence microscopy. All the results demonstrated that the probe Cy-ArB is a powerful tool for the detection of $\mathrm{H}_{2} \mathrm{O}_{2}$ concentration fluctuations.

\section{Visualization of $\mathrm{H}_{2} \mathrm{O}_{2}$ during cell $\mathrm{I} / \mathrm{R}$ process}

Encouraged by the results for the detection of $\mathrm{H}_{2} \mathrm{O}_{2}$ concentration fluctuations in cells, we intended to explore $\mathrm{H}_{2} \mathrm{O}_{2}$ concentration fluctuations in five different cell groups during the I/R process by Cy-ArB: (1) control group (group a); (2) glucose deprivation/reperfusion group (group b); (3) serum deprivation/reperfusion group (group c); (4) oxygen deprivation/ reperfusion group (group d); and (5) glucose-serum-oxygen deprivation/reperfusion group (group e). HepG2 cells were incubated with $10 \mu \mathrm{M} \mathrm{Cy}-\mathrm{ArB}$, and the images were recorded 


\section{Overlay images Colocalization areas}

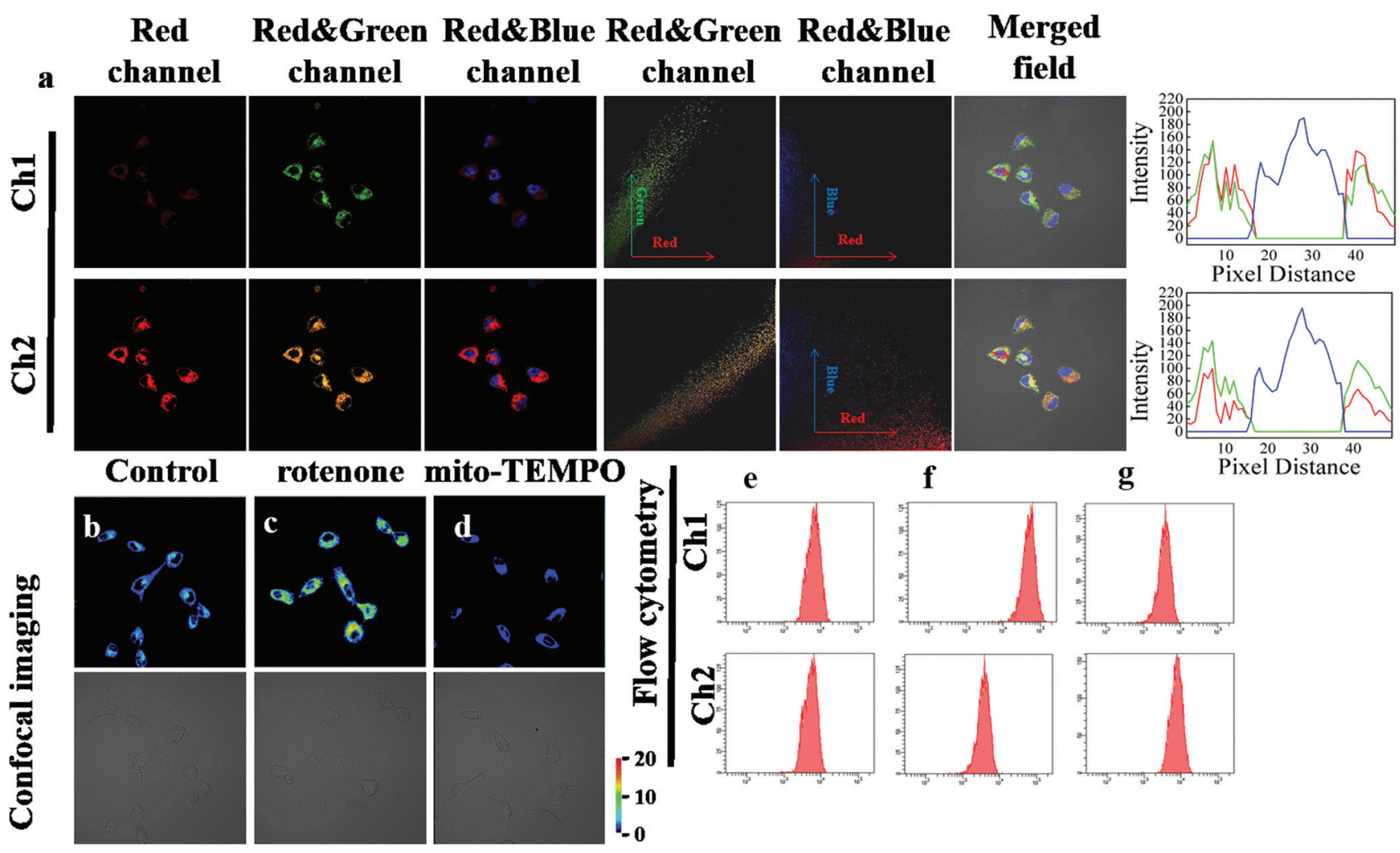

Fig. 2 (a) HepG2 cells were treated with Cy-ArB $(10 \mu \mathrm{M})$ for $15 \mathrm{~min}$, and Rhodamine $123\left(1 \mu \mathrm{g} \mathrm{mL}^{-1}\right)$ and Hoechst $33342\left(1 \mu \mathrm{g} \mathrm{mL}{ }^{-1}\right)$ for $30 \mathrm{~min}$, Ch1: $\lambda_{\mathrm{ex}}=635 \mathrm{~nm}, \lambda_{\mathrm{em}}=720 \mathrm{~nm}-770 \mathrm{~nm} ; \mathrm{Ch} 2: \lambda_{\mathrm{ex}}=730 \mathrm{~nm}, \lambda_{\mathrm{em}}=790 \mathrm{~nm}-820 \mathrm{~nm}$. For interpretation of the references to color in this figure legend, the fluorescence imaging channel is referred to as the pseudo-red channel, the mitochondrial imaging channel is referred to as the pseudo-green channel, and the nucleus imaging channel is referred to as the pseudo-blue channel. (b) HepG2 cells were treated with Cy-ArB (10 $\mu \mathrm{M})$ for 30 min. (c) HepG2 cells were treated with rotenone $(20 \mu \mathrm{M})$ for $30 \mathrm{~min}$, and then HepG2 cells were treated with Cy-ArB (10 $\mu \mathrm{M})$ for 30 min. (d) HepG2 cells were treated with mito-TEMPO $(100 \mu \mathrm{M})$ for $30 \mathrm{~min}$, and then the HepG2 cells were treated with Cy-ArB $(10 \mu \mathrm{M})$ for 30 min. (e)-(g) Flow cytometry analysis of (b)-(d).

by confocal fluorescence microscopy at $0 \mathrm{~min}, 30 \mathrm{~min}$ and 60 min. As shown in Fig. 3a and b, group a showed a weak ratio fluorescence signal which indicated normal endogenous $\mathrm{H}_{2} \mathrm{O}_{2}$ concentration in the mitochondrial respiratory chain. By comparison, the ratios of the fluorescence signals in groups b-e obviously increased in the following order: e $>d>c>b>a$. These results indicated endogenous $\mathrm{H}_{2} \mathrm{O}_{2}$ levels elevated during the $\mathrm{I} / \mathrm{R}$ process, especially in group e. The ROS burst might aggravate the oxidative damage of the cells, tissue, and organism during the $\mathrm{I} / \mathrm{R}$ process.

We then tested cell apoptosis in these cell models. The mitochondrial membrane potential $\left(\Delta \Psi_{\mathrm{m}}\right)$ could clearly reflect the early apoptotic stage of the cells, ${ }^{57}$ and we chose JC-1 as the marker of $\Delta \Psi_{\mathrm{m}}$. A Cell Apoptosis Detection Kit (Annexin $\mathrm{V} / 7-\mathrm{AAD}$ ) was used to demonstrate cell early apoptosis, late apoptosis and necrosis during the cell I/R process. As shown in Fig. 3d and e, the different degrees of cell damage in the $\mathrm{I} / \mathrm{R}$ process could be sorted as: $\mathrm{e}>\mathrm{d}>\mathrm{c}>\mathrm{b}>\mathrm{a}$, which suggested a strong relationship between cell oxidative damage and the cell $\mathrm{I} / \mathrm{R}$ process. In other words, our probe was a good tool for evaluating cell damage in the $\mathrm{I} / \mathrm{R}$ process through monitoring endogenous $\mathrm{H}_{2} \mathrm{O}_{2}$ levels.

\section{Imaging of endogenous $\mathrm{H}_{2} \mathrm{O}_{2}$ levels in vivo}

After detecting the endogenous $\mathrm{H}_{2} \mathrm{O}_{2}$ level in living cells, we attempted to prove the capability of the probe for $\mathrm{H}_{2} \mathrm{O}_{2}$ detection in vivo. Mouse liver I/R models were built as introduced in the Experimental section (Fig. $4 \mathrm{a}$ and b). Cy-ArB solution $\left(10 \times 10^{-6} \mathrm{M}, \mathrm{DMSO} / \mathrm{saline}, 1: 1, \mathrm{v} / \mathrm{v}\right)$ was prepared for the experiments. The mice were treated with two methods. After the mice were anesthetized, Cy-ArB was injected into the portal vein of the mice. The signals were obtained from two fluorescence channels at $0 \mathrm{~h}, 0.5 \mathrm{~h}, 3 \mathrm{~h}$, and $6 \mathrm{~h}$ (Ch1: $\lambda_{\text {ex }}=$ $730 \mathrm{~nm}, \lambda_{\mathrm{em}}=790 \mathrm{~nm}-820 \mathrm{~nm}$ and Ch2: $\lambda_{\mathrm{ex}}=600 \mathrm{~nm}, \lambda_{\mathrm{em}}=$ $720 \mathrm{~nm}-770 \mathrm{~nm}$ ) (Fig. 4c). Compared with the sham group, the fluorescent signal in the $\mathrm{I} / \mathrm{R}$ group increased with time (Fig. $4 \mathrm{~d}$ and e). In the I/R group, the ratio of the fluorescence signal increased within $30 \mathrm{~min}$, and then consistently increased in the process of ischemia for $2.5 \mathrm{~h}$. As we expected, the ratio of the fluorescence signal significantly increased in 

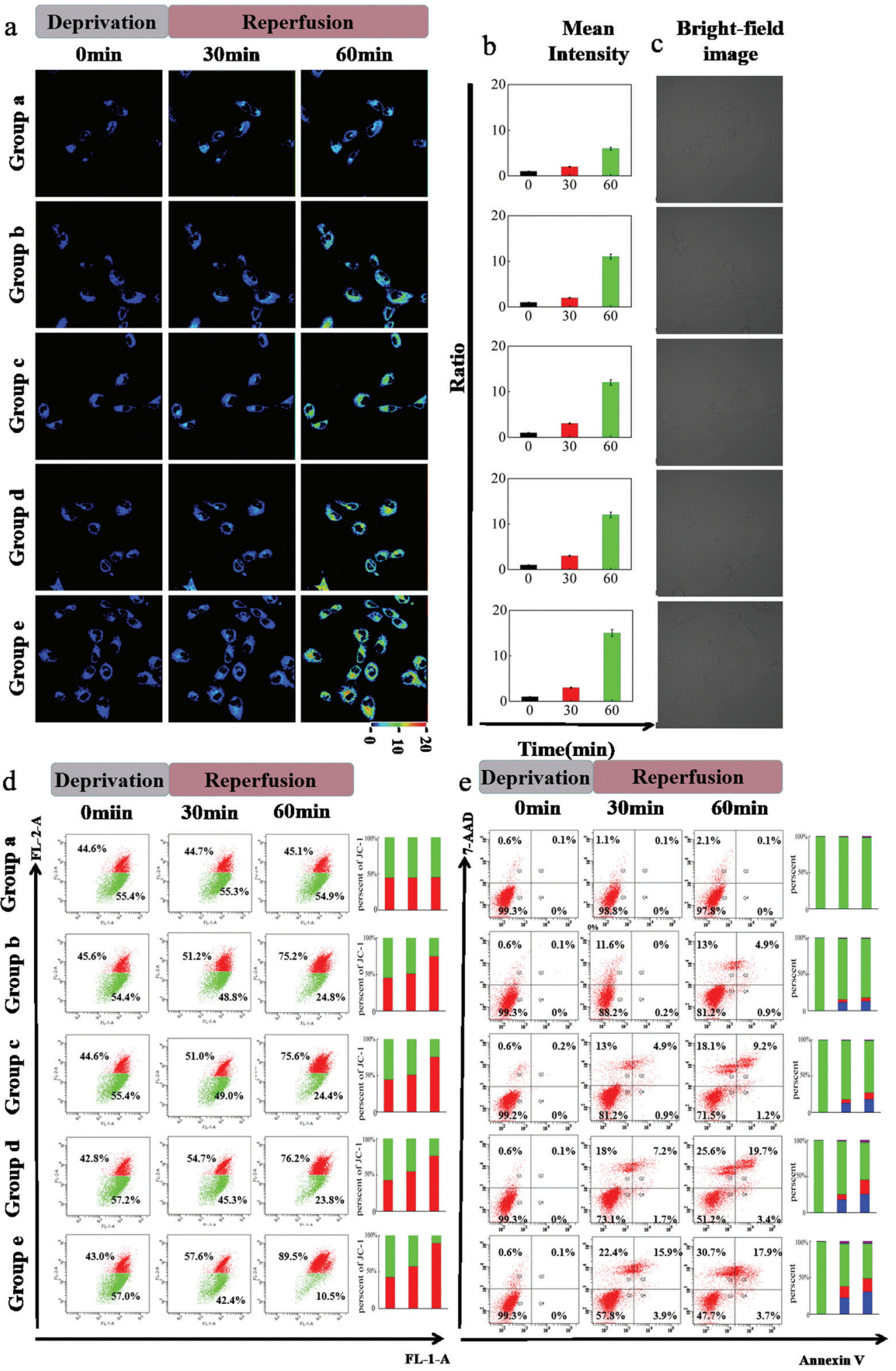

Fig. 3 The cell apoptosis through flow cytometry analysis and ratio images during the I/R process. (a) Ratio images of $\mathrm{H}_{2} \mathrm{O}_{2}$ at the time point 0 min, $30 \mathrm{~min}$ and $60 \mathrm{~min}$ in five different experimental processes. (b) The average ratio values in panel a. (c) The bright-field images of the corresponding five experiment cells. (d) $\Delta \Psi_{m}$ analyzed by JC-1. (e) Apoptosis analysis by Annexin V/7-AAD: viable cells (AnnexinV_/7-AAD_), early apoptosis

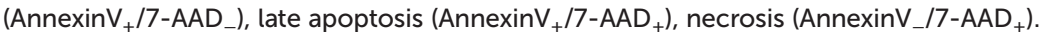




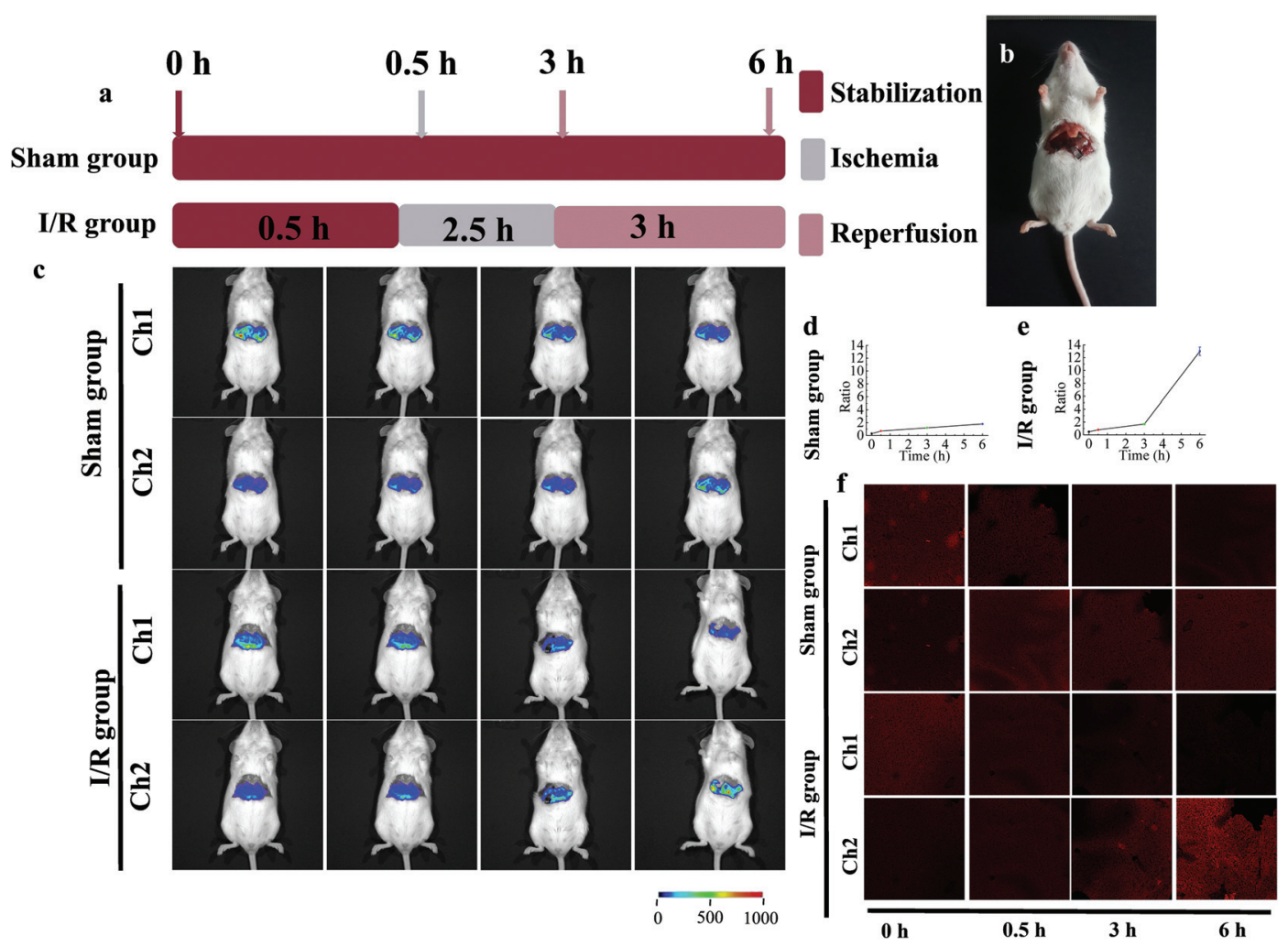

Fig. 4 In vivo imaging of endogenous $\mathrm{H}_{2} \mathrm{O}_{2}$. (a) Graphical representation of the construction method of (1) the liver sham group: control; and (2) the I/R group: normal hepatic blood circulation for $0.5 \mathrm{~h}$, hepatic portal occlusion for $2.5 \mathrm{~h}$, and hepatic blood circulation recovery for $3 \mathrm{~h}$. (b) Mouse models for hepatic ischemia. (c) In vivo imaging for the above two models. (d), (e) Mean intensities of (a). (f) Fluorescence imaging of the liver sections; the tissue sections were collected from the above two models at the time points $0 \mathrm{~h}, 0.5 \mathrm{~h}, 3 \mathrm{~h}$, and $6 \mathrm{~h}$.

the reperfusion process from $3 \mathrm{~h}$ to $6 \mathrm{~h}$. These results indicated that the reperfusion process could induce $\mathrm{H}_{2} \mathrm{O}_{2}$ outburst.

In order to further confirm our results, we performed liver tissue imaging by laser scanning confocal microscopy. The signals were obtained from two fluorescence channels: Ch1 (channel 1: $\lambda_{\mathrm{ex}}=730 \mathrm{~nm}, \lambda_{\mathrm{em}}=790 \mathrm{~nm}-820 \mathrm{~nm}$ ) and Ch2 (channel 2: $\lambda_{\mathrm{ex}}=600 \mathrm{~nm}, \lambda_{\mathrm{em}}=720 \mathrm{~nm}-770 \mathrm{~nm}$ ). The results from mouse liver tissue were consistent with those from fluorescence imaging of mice (Fig. 4f). The results demonstrated that our probe could be applied to the visualization of liver damage during $\mathrm{I} / \mathrm{R}$ processes in vivo.

\section{Conclusion}

In summary, we have developed a fluorescent probe, Cy-ArB, based on heptamethine cyanine for monitoring endogenous $\mathrm{H}_{2} \mathrm{O}_{2}$ in living cells and in vivo, especially for exploring the fluctuation of endogenous $\mathrm{H}_{2} \mathrm{O}_{2}$ during $\mathrm{I} / \mathrm{R}$ processes. In $\mathrm{I} / \mathrm{R}$ cell models, the probe could reflect the relationship between the degree of cell damage and the level of $\mathrm{H}_{2} \mathrm{O}_{2}$. In a mouse model of liver I/R, Cy-ArB could also monitor the degree of liver damage. These results confirm that our probe is a powerful tool for $\mathrm{H}_{2} \mathrm{O}_{2}$ detection during $\mathrm{I} / \mathrm{R}$ processes in vitro and in vivo, and will be beneficial for clinical surgery pre-evaluation.

\section{Conflicts of interest}

There are no conflicts to declare.

\section{Acknowledgements}

This work was financially supported by the National Nature Science Foundation of China (21575159; 21778026; 81573393), the Program of the Youth Innovation Promotion Association, CAS (2017256; 2019217), the National Key Scientific Instrument and Equipment Development Projects (2013YQ17052506), and the Instrument Developing Project of the Chinese Academy of Sciences (YZ201662).

All biological experimentations were performed with strict observance of the National Guidelines for the Care and Use of Laboratory Animals, and the experimental protocols were approved by the Institutional Animal Care and Use Committee in Binzhou Medical University, Yantai, China.

\section{References}

1 Y. Huang, F. Yu, J. Wang and L. Chen, Anal. Chem., 2016, 88, 4122-4129.

2 F. C. Fang, Nat. Rev. Microbiol., 2004, 2, 820-832. 
3 E. Kim, S. Bhuniya, H. Lee, H. Kim, C. Cheong, S. Maiti, K. Hong and J. Kim, J. Am. Chem. Soc., 2014, 136, 1388813894.

4 W. Wu, J. Li, L. Chen, Z. Ma, W. Zhang, Z. Liu, Y. Cheng, L. Du and M. Li, Anal. Chem., 2014, 86, 9800-9806.

5 R. F. van Golen, T. M. van Gulik and M. Heger, Free Radicals Biol. Med., 2012, 52, 1382-1402.

6 G. K. Glantzounis, H. J. Salacinski, W. Yang, B. R. Davidson and A. M. Seifalian, Liver Transpl., 2005, 11, 1031-1047.

7 H. Cerwenka, G. Khoschsorur, H. Bacher, G. Werkgartner, A. El-Shabrawi, F. Quehenberger, H. Rabl and H. J. Mischinger, Free Radical Res., 1999, 30, 463-469.

8 M. Valko, D. Leibfritz, J. Moncol, M. T. Cronin, M. Mazur and J. Telser, Int. J. Biochem. Cell Biol., 2007, 39, 44-84.

9 M. Giorgio, M. Trinei, E. Migliaccio and P. G. Pelicci, Nat. Rev. Mol. Cell Biol., 2007, 8, 722-728.

10 J. St-pierre, J. A. Buckingham, S. J. Roebuck and M. D. Brand, J. Biol. Chem., 2002, 277, 44784-44790.

11 B. C. Dickinson, D. Srikun and C. J. Chang, Curr. Opin. Chem. Biol., 2010, 14, 50-56.

12 X. Han, R. Wang, X. Song, F. Yu, C. Lv and L. Chen, Biomaterials, 2018, 156, 134-146.

13 K. Umezawa, M. Yoshida, M. Kamiya, T. Yamasoba and Y. Urano, Nat. Chem., 2017, 9, 279-286.

14 X. Jiang, J. Chen, A. Bajić, C. Zhang, X. Song, S. L. Carroll, Z. L. Cai, M. Tang, M. Xue, N. Cheng, C. P. Schaaf, F. Li, K. R. MacKenzie, A. C. M. Ferreon, F. Xia, M. C. Wang, M. Maletić-Savatić and J. Wang, Nat. Commun., 2017, 8, 16087.

15 M. Gao, F. Yu, C. Lv, J. Choo and L. Chen, Chem. Soc. Rev., 2017, 46, 2237-2271.

16 Y. Wang, M. Gao and Q. Chen, Anal. Chem., 2018, 90, 97699778.

17 F. Yu, X. Han and L. Chen, Chem. Commun., 2014, 50, 12234-12249.

18 J. Miao, Y. Huo, X. Lv, Z. Li, H. Cao, H. Shi, Y. Shi and W. Guo, Biomaterials, 2016, 78, 11-19.

19 H. Zhu, J. Fan, J. Du and X. Peng, Acc. Chem. Res., 2016, 49, 2115-2126.

20 X. Li, X. Gao, W. Shi and H. Ma, Chem. Rev., 2014, 114, 590-659.

21 J. Xu, Y. Zhang, H. Yu, X. Gao and S. Shao, Anal. Chem., 2016, 88, 1455-1461.

22 Y. Wen, K. Liu, H. Yang, Y. Liu, L. Chen, Z. Liu, C. Huang and T. Yi, Anal. Chem., 2015, 87, 10579-10584.

23 B. C. Dickinson, V. S. Lin and C. J. Chang, Nat. Protoc., 2013, 8, 1249-1259.

24 X. Li, X. Gao, W. Shi and H. Ma, Chem. Rev., 2014, 114, 590-659.

25 S. Li, L. Zhang, S. Zhu, X. Lv, Z. Duan and H. Wang, Nanoscale, 2017, 9, 16005-16011.

26 L. Zhang, S. Li, M. Dong, Y. Jiang, S. Zhang, X. Lv, L. Chen and H. Wang, Biosens. Bioelectron., 2017, 87, 1036-1043.

27 H. Wang, S. Li, Y. Si, N. Zhang, Z. Sun, H. Wu and Y. Lin, Nanoscale, 2014, 6, 8107-8116.

28 B. C. Dickinson and C. J. Chang, J. Am. Chem. Soc., 2008, 130, 9638-9639.
29 Z. Shen, B. Prasai, Y. Nakamura, H. Kobayashi, M. S. Jackson and R. L. McCarley, ACS Chem. Biol., 2017, 12, 1121-1132.

30 H. G. Kuivila and A. G. Armour, J. Am. Chem. Soc., 1957, 79, 5659-5662.

31 D. Kim, G. Kim, S.-J. Nam, J. Yin and J. Yoon, Sci. Rep., 2015, 5, 8488.

32 Y. C. Yang and W. L. Tseng, Anal. Chem., 2016, 88, 53555362.

33 J. Xu, Y. Zhang, H. Yu, X. Gao and S. Shao, Anal. Chem., 2016, 88, 1455-1461.

34 J. Liu, J. Ren, X. Bao, W. Gao, C. Wu and Y. Zhao, Anal. Chem., 2016, 88, 5865-5870.

35 K. Liu, H. Shang, X. Kong, M. Ren, J. Y. Wang, Y. Liu and W. Lin, Biomaterials, 2016, 100, 162-171.

$36 \mathrm{~J} . \mathrm{Xu}, \mathrm{Q}$. Li, Y. Yue, Y. Guo and S. Shao, Biosens. Bioelectron., 2014, 56, 58-63.

37 M. Ren, B. Deng, J. Y. Wang, X. Kong, Z. R. Liu, K. Zhou, L. He and W. Lin, Biosens. Bioelectron., 2016, 79, 237243.

38 Z. Han, X. Liang, X. Ren, L. Shang and Z. Yin, Chem. Asian J., 2016, 11, 818-822.

39 E. W. Miller, O. Tulyanthan, E. Y. Isacoff and C. J. Chang, Nat. Chem. Biol., 2007, 3, 263-267.

40 B. Zhu, H. Jiang, B. Guo, C. Shao, H. Wu, B. Du and Q. Wei, Sens. Actuators B, 2013, 186, 681-686.

41 X. Xie, X. Yang, T. Wu, Y. Li, M. Li, Q. Tan, X. Wang and B. Tang, Anal. Chem., 2016, 88, 8019-8025.

42 X. Li, X. Gao, W. Shi and H. Ma, Chem. Rev., 2014, 114, 590-659.

43 S. T. Manjare, Y. Kim and D. G. Churchill, Acc. Chem. Res., 2014, 47, 2985-2998.

44 H. Xiao, J. Li, J. Zhao, G. Yin, Y. Quan, J. Wang and R. Wang, J. Mater. Chem. B, 2015, 3, 1633-1638.

45 V. Massey and D. Edmondson, J. Biol. Chem., 1970, 245, 6595-6598.

46 D. Edmondson, V. Massey, G. Palmer, L. M. Beachan III and G. B. ELion, J. Biol. Chem., 1972, 247, 1597-1604.

47 R. M. Uppu, Anal. Biochem., 2006, 354, 165-168.

48 H. Maeda, K. Yamamoto, Y. Nomura, I. Kohno, L. Hafsi, N. Ueda, S. Yoshida, M. Fukuda, Y. Fukuyasu, Y. Yamauchi and N. Itoh, J. Am. Chem. Soc., 2005, 127, 68-69.

49 J. C. Morris, J. Phys. Chem., 1966, 70, 3798.

50 J. A. Terao, A. Nagao, D. K. Park and B. P. Lim, Methods Enzymol., 1992, 213, 454-460.

51 B. Chance, H. Sies and A. Boveris, Proc. Natl. Acad. Sci. U. S. A., 1988, 85, 3175-3179.

52 J. M. Aubry, B. Cazin and F. Duprat, J. Org. Chem., 1989, 54, 726-728.

53 M. N. Peyrat-Maillard, M. E. Cuvelier and C. Berset, J. Am. Oil Chem. Soc., 2003, 80, 1007.

54 S. B. King and H. T. Nagasawa, Methods Enzymol., 1999, 211-220.

55 M. Kruidering, B. Van de Water, E. de Heer, G. J. Mulder and J. F. Nagelkerke, J. Pharmacol. Exp. Ther., 1997, 280, 638-649. 
56 K. K. Lee, K. Fujimoto, C. Zhang, C. T. Schwall, N. N. Alder, C. A. Pinkert, W. Krueger, T. Rasmussen and U. A. Boelsterli, Free Radicals Biol. Med., 2013, 65, 584594.

57 E. Ramesh and A. A. Alshatwi, Food Chem. Toxicol., 2013, 51, 97-105.
58 J. Zhou, Y. Li, J. Shen, Q. Li, R. Wang, Y. Xu and X. Qian, RSC Adv., 2014, 4, 51589-51592.

59 K. C. Song, H. Kim, K. M. Lee, Y. S. Lee, Y. Do and M. H. Lee, Sens. Actuators, B, 2013, 176, 850-857.

60 S. Raha and B. H. Robinson, Trends Biochem. Sci., 2000, 25, 502-508. 